\title{
Notice of redundant publication: Aerobic capacity and disease activity in children, adolescents and young adults with juvenile idiopathic arthritis $(\mathrm{JIA})$
}

\author{
Alberto Martini and Charles Spencer
}

\section{Comment on}

Philomien A Pelt, Tim Takken, Marco Brussel, Inge Witte, Aike Kruize and Nico M Wulffraat

Aerobic capacity and disease activity in children, adolescents and young adults with juvenile idiopathic arthritis (JIA).

Pediatric Rheumatology 2012, 10:27 doi:10.1186/15460096-10-27

URL http://www.ped-rheum.com/content/10/1/27/

The Editors-in-Chief would like to alert readers that due to an error during the publication process this article [1] was published twice. The original article can be found in this journal [2].

Received: 5 September 2012 Accepted: 11 September 2012

Published: 14 January 2013

\section{References}

1. Pelt PA, et al: Aerobic capacity and disease activity in children, adolescents and young adults with juvenile idiopathic arthritis (JIA). Pediatr Rheumatol 2012, 10:27.

2. Pelt PA, et al: Aerobic capacity and disease activity in children, adolescents and young adults with juvenile idiopathic arthritis (JIA). Pediatr Rheumatol 2012, 10:25.

\section{doi:10.1186/1546-0096-11-2}

Cite this article as: Martini and Spencer: Notice of redundant publication: Aerobic capacity and disease activity in children, adolescents and young adults with juvenile idiopathic arthritis (JIA).

Pediatric Rheumatology 2013 11:2.

Submit your next manuscript to BioMed Central and take full advantage of:

- Convenient online submission

- Thorough peer review

- No space constraints or color figure charges

- Immediate publication on acceptance

- Inclusion in PubMed, CAS, Scopus and Google Scholar

- Research which is freely available for redistribution 